Technical Report

\title{
Long-term Field Storage Examination of Rice Straw for Bio-ethanol Production
}

\author{
Masato ShImoyama *1, Mai KAnEKO*1, Kouji Yoshida*1, Kenji Imou*2, and Atsushi OSAKI*2 \\ (Received July 15, 2010)
}

\section{バイオエタノール製造原料用稲わらの屋外長期保管試験に伴う形態変化について \\ 下山真人*1，金子 舞*1，吉田浩爾*1，芋生憲司*2，大崎敦史*2}

\begin{abstract}
Outdoor field storage of round-baled rice straw to suppress the cost of producing bio-ethanol from rice straw was investigated. Harvested rice straw was dried, collected, compressed and packed into round bales (rolls) by a round baler. Usually, the rolls are stored in a warehouse, or outdoors wrapped in a film coat. However, these storage costs push up the price of the bio-ethanol produced and reduce energy efficiency. To avoid this, outdoor field storage of rice straw rolls with or without film wrapping (wrapped rolls or nonwrapped rolls) was investigated in this study. The rolls were stored for about 9 months, from 19 December 2008 to 9 September 2009, taking into consideration the supply of rice straw for demonstrating a bio-ethanol pilot plant throughout the year. No significant increase of temperature in each roll was observed during the storage term, even though an increase was reported in previous studies. However, the straw should be stocked for other seasons, and it is important to grasp any problems during the storage period. In this study, no significant change was observed in the non-wrapped rolls throughout the term, suggesting that non-film wrapping round-baled rice straw can be stored in fields outdoors.
\end{abstract}

\section{Key Words}

Rice straw, Long-term storage, Bio-ethanol, Outdoor

\section{1. 緒 言}

輸送活動による化石燃料消費の増大により，温室効果ガス 排出量は 2004 年に世界全体で $63 \sim 64$ 億卜ンに達して以降, 増加し続けている1)。また，資源の枯渇へ向けての価格高騰な どから石油生産量は今後10年程度でピークを迎えることが予 測されており ${ }^{2)}$, 化石燃料は持続可能性という点において複数 の問題を抱えている。再生可能資源であるバイオマスからの 輸送用液体燃料生産は, 上述の問題を解決する有効的な手段 として，持続的な社会形成の観点から着目されている ${ }^{344}$ 。一 方，現在行われている糖質ならびにデンプン質系原料からの バイオエタノール生産は, 2004年にアメリカでトウモロコシ の総生産量のおよそ10\%がバイオエタノールに使用されるな ど，食料との競合の恐れが指摘されている5)6)。この競合を回 避するため, 近年では食料と競合しないセルロース系バイオ マスからのエタノール生産が世界的に注目されており7)，わが

\footnotetext{
* 1 The Japan Association of Rural Resource Recycling Solutions 5-34-4, shinbashi, minato-ku, Tokyo 105-0004, Japan

* 2 Graduate School of Agricultural and Life Sciences, The University of Tokyo

1-1-1, Yayoi, Bunkyo-ku, Tokyo 113-8657, Japan
}

国においては主要作物である米の生産過程で副生産物的に発 生する稲わらを用いて，バイオエタノールを生産する試みが 各所で行われている ${ }^{8)}$ 。現在，国内で発生する稲わらの $75 \%$ 以上は鋤き込みなどで処分されており ${ }^{91}$ ，余劋バイオマスとし て有力な賦存量がある。この余劋の稲わらを用いて効率的に バイオエ夕ノールを生産するためには，バイオエタノールへ の変換技術もさることながら，原料確保に関する知見の集積 が必要となる。特に連続的なバイオエタノール製造を行う上 で，年間を通じた原料の安定供給は重要な課題である。この ため, 地域によっては年一度の収穫となる秋に集草した原料 稲わらを，通年にわたり安価かつ低エネルギーで保管する技 術の探索は大きな問題となっている。現在，バイオエタノー ル原料稲わらの集草・保管方法は，主に飼料用に開発された 手法の応用が検討されている ${ }^{10)}$ 。飼料向けの稲わらは，ロー ルベーラーにて円筒形に集草された後，必要に応じてスト

\footnotetext{
* 1 (社)地域資源循環技術センター 干 105-0004 東京都港区新橋 5 丁目 34 番 4 号

* 2 東京大学大学院農学生命科学研究科 干 113-8657 東京都文京区弥生 1-1-1
} 
レッチフィルムが巻かれ，保管される。このストレッチフィ ルムによる梱包は，元来屋外にてサイレージ化を促す目的で 行われ ${ }^{11)}$ ，梱包を行わない場合は倉庫にて屋内保管とするこ とが主である。これは，飼料用には高品質の稲わらが求めら れることと, 屋外に放置した場合, 腐敗し発酵熱が生じる恐 れがあること，また発熱に伴う火災の発生を恐れてのことで ある ${ }^{12)}$ 。屋外における保管に関しては，畜産飼料については 検討がなされており，例えば，牧草（アルファルファ）にお ける発酵熱の検討においては，18\%（以下含水率の值は全て 総量基準)の水分を含むもので $50^{\circ} \mathrm{C}$ ，含水率 $23 \%$ では $90^{\circ} \mathrm{C} に$ 上昇するという報告がある ${ }^{13)}$ 。一方，バイオエタノール原料 などバイオマスとしての利用を目的とした集草・保管方法に 関する研究はあまり行われていない。バイオエタノール原料 用稲わらでは，畜産飼料で求められるような家畜の嗜好性を 目的とした品質保持の必要がない一方で，大幅な保管コスト の削減が求められる。倉庫保管は，倉庫使用に伴う保管コス 卜の増大を招くことから，前述のような発酵熱による火災や 極端な劣化の恐れがなければ屋外保管とすることが望ましい。 以上のような経緯から，倉庫保管に代わるバイオエ夕ノール 原料の保管方法として，ストレッチフィルムを用いた屋外保 管が近年着目されているが，ストレッチフィルム作業工程を 挿入することで，稲わら $1 \mathrm{~kg}$ あたり 10 円のコスト ${ }^{10)}$ ，およ び稲わら $1 \mathrm{~kg}$ あたりおよそ $5 \mathrm{~g} の \mathrm{CO}_{2}$ 排出が加算されるなど の報告もあり ${ }^{14)}$ ，議論の対象となっている。

そこで我々は，バイオエ夕ノール原料向け稲わらの屋外保 管に関する知見として, 調査戋場乾燥後の稲わらをストレッ チフィルムで密封する方法(以下ラッピングロールと呼ぶ) と ストレッチフィルムを使用しない方法（以下ラップ無しロー ルと呼ぶ）の 2 通りに分け，各ロールベールについて屋外で の保管試験を行ったのでここに報告する。

\section{2. 保管試験の実施方法}

\section{1 稲わら及びロールベール保管条件}

試験に供した稲わらは，茨城県下妻市の圃場で2008年 9 月 に刈り取り後，およそ $20 \mathrm{~cm}$ に裁断し，圃場にてテッダーレー キで 2 回反転し乾燥させ，10月に芯巻き式ロールベーラーに て集草し，ネットで結束してロールベールとしたものを用い た（Fig. 1)。ラッピングロールは，上記ロールベールにスト レッチフィルム（昭和パックス(株)製スノーベール®）を４重 に巻いて，作製した。ラップ無しロールは，芯巻き方法にて ロールベールを作製し，ポリエチレン製ネットで結束したも のを用いた。稲わらロールは共に直径 $1.2 \mathrm{~m}$, 長さ $1.5 \mathrm{~m}$, 重 量約 $150 \mathrm{~kg}$ になるよう調整した。保管試験はラッピングロー ル，ラップ無しロール各 3 個，計 6 個について，下妻市に隣 接した筑西市内協力農家の同一围場内にて行った。試験围場 は裸地であったため，ロールベールは高さ $20 \mathrm{~cm}$ の木製のパ レットを敷き，その上に設置した（Fig. 1)。

\section{2 測 定}

発酵熱の発生を観察するため，温度計測用データロガーと

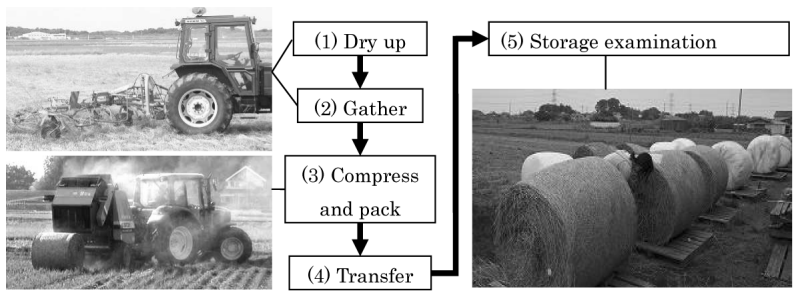

Fig. 1 Outline of straw collection and storage process

(1) Rice straw was mixed twice to dry it and (2) gathered by tedder/rake on the paddy field after 10 days. (3) After drying, the straw was collected, compressed, and packed by a round baler. Each packed roll was banded with P.E. net. (4) Packed round bales were transferred to the test storage field. (5) Outdoor field storage was performed: six rolls were installed on wooden palettes; three of the rolls were film wrapped ( 3 white rolls to rear of photo) before placement, and the other three rolls were not wrapped ( 3 gray rolls to front of photo). The other rolls in the back of the photo were not used for this study

してサーモクロン SL タイプ（(株)KN ラボラトリーズ）を各 ロールベールの中心にセットした。また比較のため外気温の 計測も行った。試験期間中, 温度は 2 時間毎に計測した。

試験は，連続的なバイオエタノール製造のため，年間を通 じて原料を供給し続けることを目的に，9月の稲刈り後，雨 天が多かったため 2 ケ月の戋場乾燥期間を設けたのち，2008 年 12 月 19 日のロールベール作成から，翌年の稲刈り期に該 当する 2009 年 9 月 9 日にかけて行った。保管試験終了後, ロールベールを解体し, 内部の状態確認と温度計測データロ ガーの回収，稲わらの含水率測定を行った。含水率測定はス テンレス製シャーレを用い， $105^{\circ} \mathrm{C} に$ 設定した三洋電機株式会 社製 MOV-212S 乾熱滅菌機を用いて恒量になるまで乾燥し, 前後の重量測定を Mettler Toledo(株)製XS-205DUで測定を行 い，この際の重量減少より試料の湿重量あたりの含水率（総 量基準）を算出する炉乾法にて実施した。

\section{3. 試験結果}

保管試験期間を通した外気温およびロールベールの中心温 度について，1 週間ごとの平均值の推移をFig. 2に示す。ロー ルベールの中心温度はほぼ外気温の平均と等しく, 発酵によ る温度上昇は認められなかった。またラッピングロール，ラッ プ無しロールに㧍ける温度変化の違いは認められなかった。 保管試験終了時のロール中心部の含水率を Table 1 に示す。 ラッピングロール，ラップ無しロール共に，終了時の中心部 分は含水率約 $12 \%$ であり, 乾燥状態が保たれていた。ただし, ラッピングロールでは一部変色が認められ，この部分の含水 率は $18.0 \%$ とやや高かった。

\section{1 ラップ無しロールの状態}

ラップ無しロールでは，試験終了時，パレットに接地して いたロール底部に変色が見られた（Fig. 3）。底部以外では， ロール外部及び内部ともに変色は認められなかった Fig. 4)。 このロール底部における変色は，パレットを敷くことにより 地面との絶縁を図ったものの, 地面からの水蒸気や降雨時の 


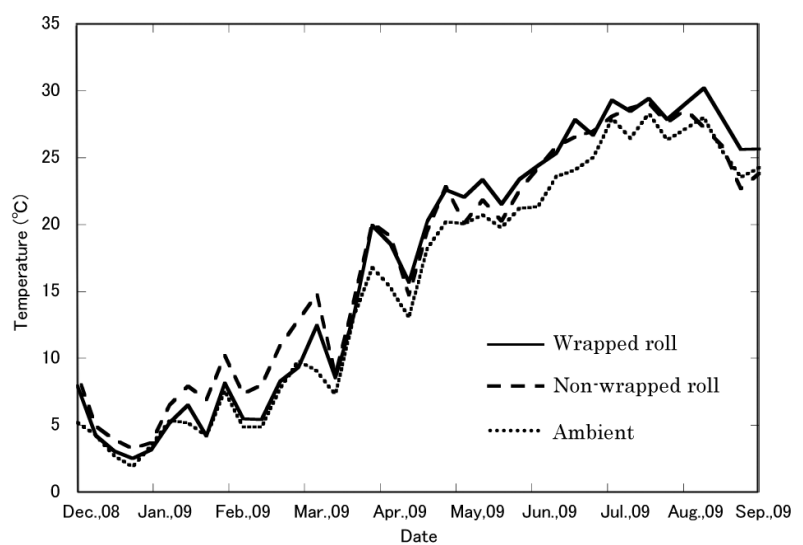

Fig. 2 Change in temperature during storage. Solid line: inner temperature of wrapped roll, broken line: inner temperature of non-wrapped roll, dotted line: ambient temperature. No significant exothermic reactions were observed

Table 1 Water content (\%, wb) of stored round bales (rolls). Each roll was kept dry except the color changed part

\begin{tabular}{l|c}
\hline \multicolumn{1}{c|}{ Roll condition } & Water content (\%, wb) \\
\hline Wrapped roll & $12.7 \%$ \\
\hline Wrapped roll (color changed part) & $18.0 \%$ \\
\hline Non-wrapped roll & $11.5 \%$ \\
\hline
\end{tabular}

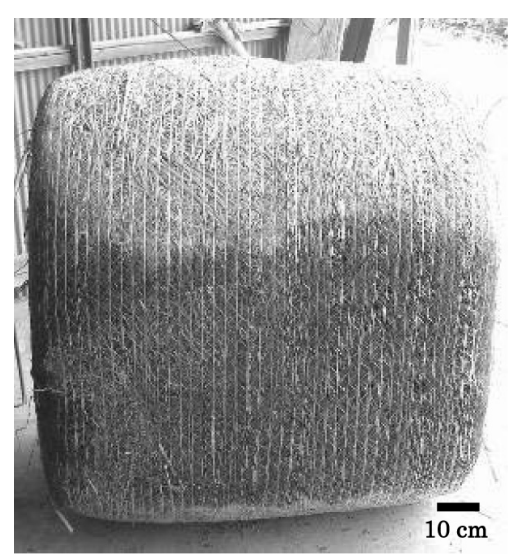

Fig. 3 Color change was observed at the bottom of non-wrapped rolls
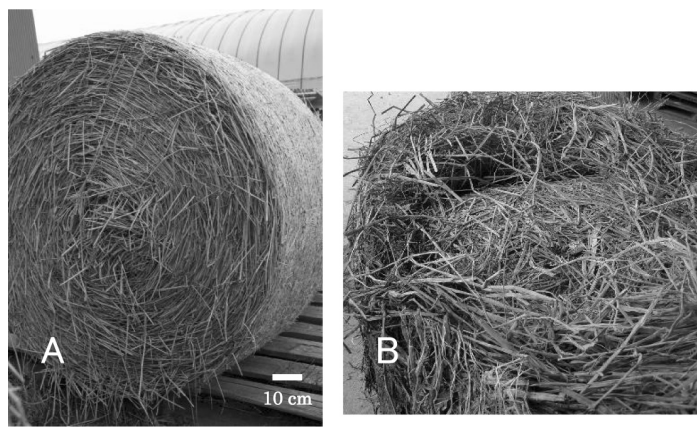

Fig. 4 A: Side part of non-wrapped roll, B: Unpacked nonwrapped roll. Color change was not observed

跳ね返りの影響が避けられなかったためと推測された。

\section{2 ラッピングロールの状態}

試験終了時のラッピングロールでは，側面に変色が見られ
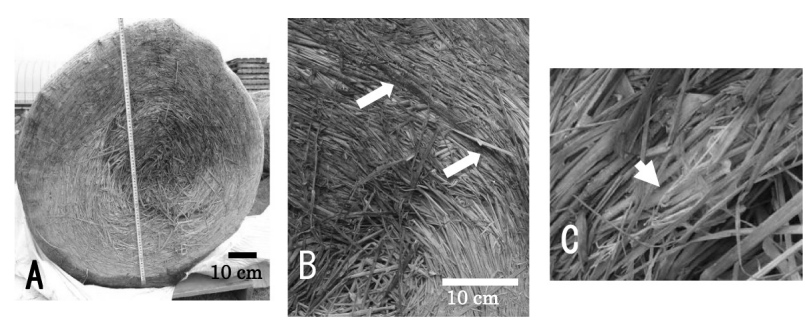

Fig. 5 Color changed side of wrapped roll (after stripping the wrapping film). Some bryophyte (arrows in B) and fungi (arrow in C) was also observed

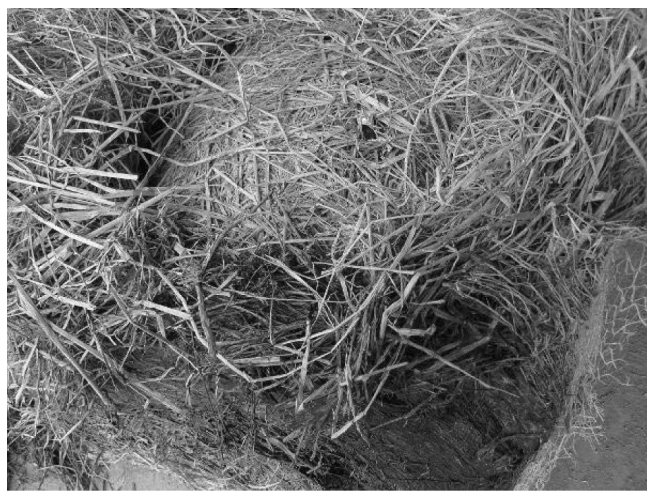

Fig. 6 Unpacked wrapped roll. Color change was not observed on the inner part of the wrapped roll

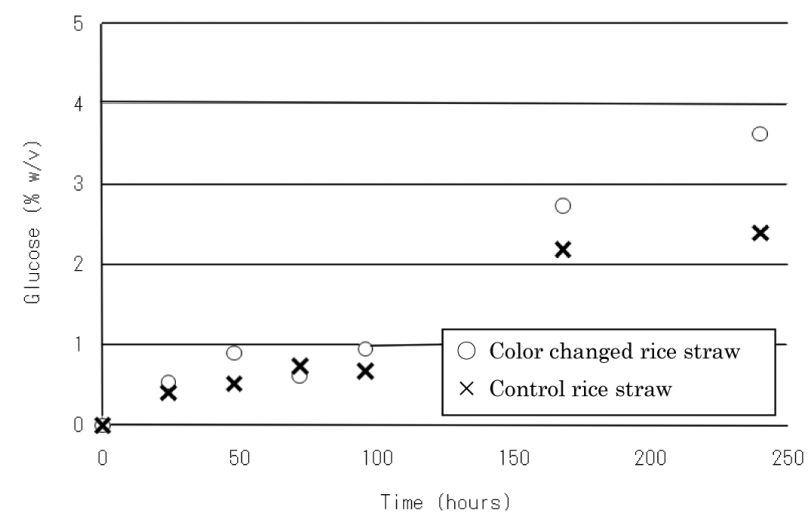

Fig. 7 Time course of glucose production from color changed rice straw (black cross), and control rice straw (white circle)

た（Fig. 5-A 上部）。また，一部コケ類の発生（Fig. 5-B）や， ロール側面中心部付近の圧縮密度が低い部分におけるカビの 発生 (Fig. 5-C) も確認された。しかし, ロール内部での変色 やカビ等の発生は認められなかった Fig. 6)。なお，変色等の 見られた稲わらについて前処理後，糖化試験を実施した結果， 変性の見られた部位からもグルコースが生成し，バイオエ夕 ノール原料として利用可能である事が示唆された (Fig. 7)。 ラップサイレージでは開封後稲わらが空気と接触することに より，酵母や系状菌などの好気性菌が増殖し，発熱を伴った 二次発酵が稲わらの変敗を引き起こすことが知られている ${ }^{15)}$ 。 本試験では, 温度ロガーの挿入やサンプリングのための開口 部を設けていたものの, 外気との接触による変色などの影響 はロール表面の限られた範囲のみで観察された。これは, ロー ル前に乾燥工程を設け，ラップサイレージに比べ稲わらの含 
水率が低い状態でラッピングを行ったためと考えられる。

\section{4. 結 論}

本試験では，芯巻き方法によりロールベールを作製し，ラッ ピングロールおよびラップ無しロールについてそれぞれ屋外 に長期間保管し，比較を行った。試験は年間を通じて原料を 供給し続けることを目的に，9月の稲刈り後 2 ケ月の固場乾 燥期間を設けたのち，平成 20 年 12 月 19 日から平成 21 年 9 月 9 日までの約 9 ヶ月間行った。

本試験において，当初予想していたような全体的な腐敗や， 発酵による発熱などの問題は認められなかった。通常，ラッ プサイレージでは発酵による温度上昇が起こるが ${ }^{16)}$, 今回用 いた稲わらは，ロール調整時に含水率15\%以下にまで乾燥し ていたことにより発酵が進まず，良好な保管状態が保たれた ものと考えられる。なお，既往の研究では含水率 $13 \%$ におい ても短期間 $50^{\circ} \mathrm{C}$ まで上昇している ${ }^{13)}$ 。この温度上昇が本試験 において観察されなかったのは，主に次の二点によるものと 考えられる。第一に，既往の研究で用いられたロールベール のサイズは $350 \mathrm{~kg} \sim 624 \mathrm{~kg}$ であり，これと比して本試験で 用いたロールベールは約 $150 \mathrm{~kg}$ と小型で，発酵熱の蓄積が抑 制された点。第二に，稲わらの易可溶性有機物は $11.4 \%$ であ り，既往の研究で用いられた牧草（アルファルファ）の 28.5 〜 38.9\%に比べそしく ${ }^{17)}$, 発酵による発熱が起こりにくい状 況にあった点である。

また，ラップ無しロールでは目視によるカビ，コケ類の発 生は見られず，ラッピングロールに比べ，より良好な状態が 保たれていたと考えられる。このことは，稲わら保管コスト 及び化石資源依存度低減の観点からも有意義な結果であると 言えよう。

調査した茨城県筑西市では, 冬季に乾燥した季節風が吹く ことから，稲わらロールベールの屋外保管にとって有利な条 件であったといえる。

筑西市に隣接する気象庁下妻観測点の気象データより，本 調査地域の降水量および日照時間は，ともに年間を通して大 きな変化は見られなかった（Fig. 8)。一方で，本調査による 外気温の変遷と (Fig. 2)，近隣に位置する水戸およびつくば気 象台の湿度の変遷データより（Fig. 9)，6月1日から試験終

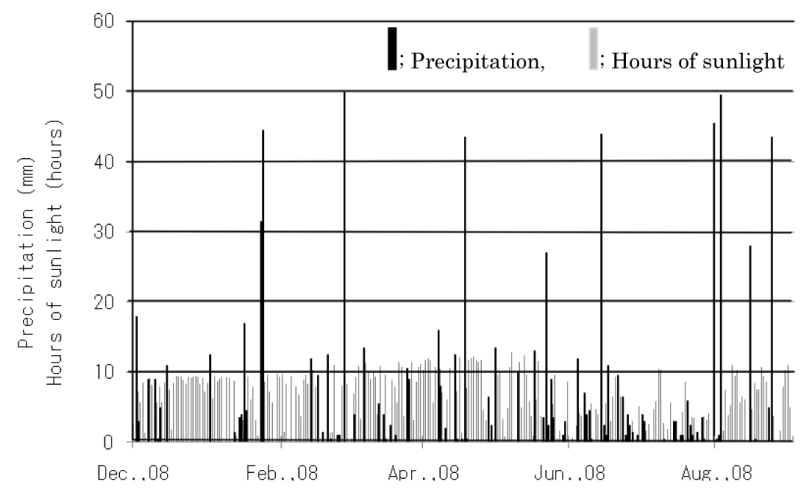

Fig. 8 Precipitation and hours of sunlight at Shimotsuma observation point during storage. Black bar indicates precipitation, and gray bar indicates hours of sunlight

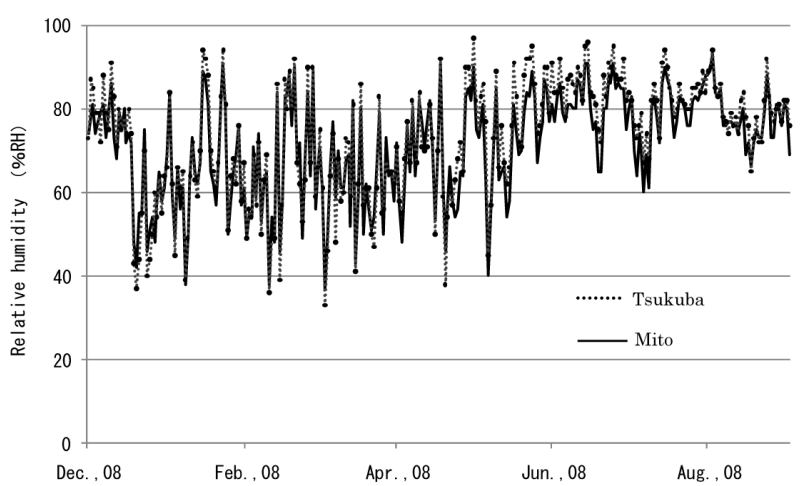

Fig. 9 Change of relative humidity observed in Tsukuba(dotted line) and Mito(black line) local meteorological observatories during storage

了の 9 月 9 日までの夏季に該当する期間，気象庁が湿潤な空 気と判断する湿度 $80 \%$ を超える日が調査日数の半数を超えた こと（試験日数 101 日あたり 55 日（水戸), 68 日（つくば））, および同期間の外気温について，気象庁が夏日と定義する 25 ${ }^{\circ} \mathrm{C}$ 以上の日数が半数を超えたことから (101日あたり51日) ${ }^{18)}$, 本調査地域における夏季は高温多湿な環境にあったと考えら れる。ラップ無しロールにおいては，このような高温多湿環 境下でも，屋外保管に扮ける大きな問題は認められなかった。

また，茨城・栃木県におけるバイオエタノール生産用稲わ らの発生密度はそれぞれ37.8，30.7 t/ $\mathrm{km}^{2}$ であり, 収集半径を $30 \mathrm{~km}$ とするとおよそ年間 2 万 $\mathrm{kL}$ のエタノールが製造可能と されている10)。よって，2万kLのエタノール生産に必要な稲 わらをエタノール収率 $0.3 \mathrm{~L} / \mathrm{kg}$ として算出すると, 重量にし ておよそ 6.6 万塤あり，この 6.6 万㴞わらの保管には，稲 わらロールの積み上げ高さを $5 \mathrm{~m}$, 間隙率 0.3 , かさ密度 150 $\mathrm{kg} / \mathrm{m}^{3}$ ，乾物率 0.85 として算出すると， $385 \mathrm{~m} \times 385 \mathrm{~m}$ でお よそ15 haの広大な面積が必要となる。このことから，考えら れる稲わらロールの保管方法としては，保管面積の制約上，前 述の試算のように密に詰め，数段に重ねることが予想される が，本試験ではロールは $50 \mathrm{~cm} \sim 1 \mathrm{~m}$ ほどの間隔をもって設 置されており，また積み重ねはしていない。そのため，通風 が確保され，重なり部分に扮ける雨水の残留などの問題が生 じる事はなかった。今後，更にこうした実際の保管条件を反 映させた屋外試験が望まれる。

\section{謝 辞}

この試験は，農林水産省ソフトセルロース利活用推進事業 の業務の一環として行われました。また，(有)倉持牧場 代表 倉持秀男様には，保管場所の提供や農機を用いた作業など，多 大なるご協力を賜りました。

\section{文 献：References}

1) Ribeiro, S. K., Kobayashi, S., IPCC AR4 Contribution of Working Group III to the Fourth Assessment Report of the Intergovernmental Panel on Climate Change, (Cambridge Univ. Press), Chapter 5, p. 333 (2007)

2) Tsoskounoglou, M., Ayerides, G., Tritopoulou, E., Energy Policy, 
36, $3797(2008)$

3）五十嵐泰夫，斉木隆，稲わら等バイオマスからのエタノー 儿生産，（(社)地域資源循環技術センター), p. 2(2008)： Igarashi, Y., Saiki, T., Inawara-tou Biomass Karano Ethanol Seisan, (JARUS), p. 2(2008)

4）横山伸也, 芋生憲司, バイオマスエネルギー,（森北出 版), p. 89(2009) : Yokoyama, S., Imou, K., Biomass Energy, (Morikita Shuppan), p. 89 (2009)

5）レスター・R・ブラウン，福岡克也(訳)，フードセキュリ ティー-誰が世界を養うのか-, （ワールドウォッチジャパ ン), p. 297(2006) : Brown, L. R., Outgrowing The Earth: The Food Security Challenge in an Age of Falling Water Tables and Rising Temperatures, (W. W. Norton \& Co. Inc.), p. $297(2004)$

6）久保田宏，松田智，幻想のバイオ燃料，（日刊工業新聞 社), p. 68 (2009) : Kubo, H., Matuda, S., Gensou no Bionenryou, (Nikkankougyou Sinbunsya) , p. 68 (2009)

7) Dipardo, J., Outlook for Biomass Ethanol Production and Demand, (Energy Information Administration), p. 1 (2004)

8）斉木隆，バイオエタノール通信，（地域資源循環技術セン ター), No. 2, p. 32(2009):Saiki, T., Bio-Ethanol Tsuushin, (JARUS) , No. 2, p. 32 (2009)

9）農林水産省, 飼料をめぐる情勢, (2008) : Ministry of Agriculture, Forestry and Fisheries, Shiryou Wo Meguru Jousei, (2008)

10）佐賀清崇，芋生憲司，横山伸也，藤本真司，柳田高志，美
濃輪智朗，エネルギー・資源学会論文誌, 29 (6), 8 (2008)： Saga, K., Imou, K., Yokoyama, S., Fujimoto, S., Yanagida, T., Minowa, T. Journal of Japan Society of Energy and Resources, 29 (6), 8(2008)

11）萬田富治，ラップサイレージの調整と利用，（酪農総合研 究所), p. 29 (1999) : Manda, T., Wrap Silage No Chousei To Riyou, (Research \& Development Center For Dairy Farming), p. 29(1999)

12) Kennedy, M., Australasian Biotechnology, 7(2), $104(1997)$

13) Baxter, H. D., J. Dairy. Sci., 69, 1847 (1986)

14）昔農英夫, 芋生憲司, 横山伸也, 農業環境工学関連学会 2009年合同大会講演要旨集, E42 (2009)：Sekino, H., Imou, K., Yokoyama, S., Joint Conference on Environmental Engineering in Agriculture 2009 Kouen-Youshi-shuu, E42(2009)

15）斉藤健一, 米本貞夫, 千葉畜七研報, 2, 9(2002)：Saitou, K., Yonemoto, S., Bulletin of the Chiba Prefectural Livestock Research Center, 2, 9(2002)

16）系川信弘，本田善文，小林亮英，日草誌，40(4)，478 (1995) : Itokawa, N., Honda, Y., Kobayashi, A., Nihon Souchi Gakkai Shi, 40 (4), 478(1995)

17）阿部亮, 名久井忠, 日草誌, 25(3), 231 (1979) : Abe, A., Nakui, T., Nihon Souchi Gakkai Shi, 25(3), 231 (1979)

18）気象庁が天気予報等で用いる予報用語，http://www.jma. go.jp/jma/kishou/know/yougo_hp/mokuji.html(2010/9/24 参照) : Meteorological term that the Meteorological Agency uses for the weather forecast 